\title{
Magnitude yield response and economic value of selected wheat genotypes related to irrigation schedules under the arid ecosystem of Saudi Arabia
}

\author{
A. A. Alderfasi ${ }^{1} \&$ A. A. AL-Owayed ${ }^{2}$ \\ ${ }^{I}$ Plant Production Department, \\ Faculty of Food and Agricultural Sciences, King Saud University, \\ Saudi Arabia \\ ${ }^{2}$ Biology Department, Faculty of Sciences, \\ The Princess Noura Bint Abdelrahman University for Girls, Saudi Arabia
}

\begin{abstract}
The greatest challenges facing the improvement of agriculture programs under arid and semiarid environment are those involving the provision of water. Thus, field experiments have been carried out in a split-plot design at the Agricultural Research Station, Faculty of Food and Agricultural Sciences, King Saud University. The experiments included 20 treatments, four wheat genotypes, (Yecora Rojo, West bread, KSU 102 and KSU 105) and five irrigation schedules $(50,100,150,200 \mathrm{~mm})$ of cumulative pan evaporation CPE, as compared to traditional irrigation methods used by many farmers (weekly irrigation). The total amount of water supplied over the growing season was calculated. The data obtained clearly indicated that a gradual decrease in most of the yield and yield component characters were in line with decreasing irrigation schedules. The results also showed that no significant differences were found between irrigation schedules at $50 \mathrm{~mm}$ of CPE and weekly irrigation in most of the studied characters, except on biological yield, which was similar to traditional irrigation. In addition, significant differences among wheat genotypes were observed in all traits. The KSU 105 genotype ranked in the first position and surpassed the other tested genotypes. The interaction between irrigation schedules and genotypes was also significant for grain yield. Economic evaluation showed that the highest invested return per SR and net return in SR was obtained by irrigating wheat at
\end{abstract}


$50 \mathrm{~mm}$, followed by $100 \mathrm{~mm}$ CPE. Finally, we can conclude that at least $20 \%$ of water irrigation could be conserved to achieve high grain yield.

Keywords: wheat genotypes, arid environment, drought resistance, irrigation schedules, CPE, economic value.

\section{Introduction}

Interest in crop response to environment stress has increased greatly in recent years because severe losses may result from heat, cold, drought and high concentrations of salts in the available water used in irrigation. On a global basis, drought (assumed to be soil and/or atmospheric water deficit), in conjunction with coincident high temperature and radiation, poses the most important environmental constraint to plant survival and crop productivity. Several studies indicated that wheat grains showed a high response to soil moisture stress. The magnitude of yield reduction from water deficits in wheat genotypes depends upon the growth stage at which the water deficiency occurs and the severity and duration of the deficiency (Salter and Goode [1]; Misra et al [2]; Chauhan et al [3] and Abd el Ghany [4]).

Saudi Arabia, like many other countries located in the arid and semiarid regions of the world, faces the problem of limited water resources (Hussain and Al-Jaloud [5] and Ghandorah et al [6]). Wheat is a major crop of such areas. Although wheat is considered as being fairly tolerant to drought, its yield is drastically reduced due to low soil moisture (Kramer and Boyer [7] and Alderfasi et al [8]). Moisture stress at any stage of crop growth can cause an irreversible loss in yield potential. The severity of loss depends on many factors, such as timing, length and severity of the drought period. Moreover, yield reduction can be due to the reversible effects in the number of tillers, reduced kernel weight or fewer kernels (Reginato [9] and Reginato and Carrot [10]). Under such conditions it was necessary to develop efficient reliable and economical irrigation management strategies for effective use of the existing limited water resources (Imtiyaz et al [11, 12]). The traditional method for irrigation scheduling that depends on time intervals is not efficient, and improper irrigation management practices do waste scarce water resources. Therefore, it is essential to develop these methods through untraditional ways. One of these efficient reliable methods is cumulative pan evaporation (CPE). Using the ratio between irrigation water applied and CPE has been accepted by many researchers due to its simplicity and data availability [12-14]. Due to lack of proper irrigation scheduling techniques, the average yield of wheat and other field crops is low either due to excess or deficit soil moisture regimes. In respect of genotypic variation effect, several investigators have found that this appears to give great response, since specific ones surpassed others significantly in wheat yield and its components (El-Haddad et al [15], Yousef and Hanna [16], ElBeially [17], Hassan et al [18], Abd Allah et al [19] and Reiad et al [20]). The importance of water stress genotypes could be more accurately predicated with a clear picture of the relationships between growth stages and plant response to water stress. Keeping in mind the above mentioned review of literature, the 
present study was proposed to clarify the relationship between yield productivity and water schedules for some wheat genotypes. In addition, economical evaluation was planned as an additional target.

\section{Materials and methods}

\subsection{Plant materials}

Four wheat genotypes (two cultivar varieties Yecora Rojo and West bread and two advanced lines KSU 102 and KSU 105) were tested in a field experiment. The pedigree and identification of the genotypes used are presented in Table 1.

\subsection{Water irrigation schedules}

Traditional irrigation used by many farmers (weekly irrigation) plus four irrigation schedules at cumulative pan evaporation (CPE) of 50, 100, 150 and $200 \mathrm{~mm}$ during the entire crop growth period with the depth of $50 \mathrm{~mm}$ at each

Table 1: $\quad$ Pedigree and identification of the four wheat genotypes used.

\begin{tabular}{|c|c|c|c|}
\hline Genotype & Pedigree & Maturity group & Origin and specific features \\
\hline KSU 102 & $\begin{array}{c}\text { Yecora Rojo x } \\
\text { local varity sama }\end{array}$ & Medium & $\begin{array}{c}\text { King Saud Univeristy, Faculty of } \\
\text { Food and Agriculture Science, } \\
\text { Plant Production Program }\end{array}$ \\
\hline KSU 105 & RI 474 x HD2172 & Medium & $\begin{array}{c}\text { King Saud Univeristy, Faculty of } \\
\text { Food and Agriculture Science, } \\
\text { Plant Production Program }\end{array}$ \\
\hline Yecora Rojo & Cultivar variety & $\begin{array}{c}\text { Semidwarf early } \\
\text { mature }\end{array}$ & USA \\
\hline $\begin{array}{c}\text { West } \\
\text { bread }\end{array}$ & Cultivar variety & Late mature & USA \\
\hline
\end{tabular}

Table 2: Number of irrigation and amount of water used for each treatment over the growing season (means of the two growing seasons of 2003/2004 and 2004/2005).

\begin{tabular}{|c|c|c|}
\hline Water supply treatments & $\begin{array}{c}\text { Mean of water apply } \\
\text { over growing season } \\
\left(\mathrm{m}^{3} / \mathrm{ha}\right)\end{array}$ & $\begin{array}{c}\text { Mean of number of } \\
\text { irrigations over growing } \\
\text { season }\end{array}$ \\
\hline Weekly irrigation & 10000 & 20 \\
\hline Irrigation at $50 \mathrm{CPE}$ & 8000 & 16 \\
\hline Irrigation at $100 \mathrm{CPE}$ & 6000 & 12 \\
\hline Irrigation at $150 \mathrm{CPE}$ & 4000 & 8 \\
\hline Irrigation at $200 \mathrm{CPE}$ & 2000 & 4 \\
\hline
\end{tabular}


irrigation (this depth of irrigation water is good enough to bring the soil to its field capacity). The CPE was calculated as a sum of daily-recorded evaporation from USWB class A open pan. Irrigation schedules were compared with the control (weekly irrigated) as a traditional method used by many farmers in the area of the experiment. At the end of the experiments the total amount of water supplied was calculated and is presented in Table 2.

\subsection{Field experiments}

Two field experiments were conducted during the winter seasons of 2003/2004 and 2004/2005 at the Agricultural Research Station, Derab, near Riyadh, Saudi Arabia $\left(24^{0} 42^{\prime} \mathrm{N}\right.$ latitude and $46^{\circ} 44^{\prime}$ E longitudes, Alt $\left.600 \mathrm{~m}\right)$. The climate in this region of the Saudi Arabia Kingdom has been classified as an arid climate. Before commencement of the field experiments, samples of the soil sites were taken for physical and chemical analyses according to the methods described by Cottenie et al [21] and But [22]. The results revealed that the soil sites were sandy-clay-loam texture ( $65 \%$ sand, $13 \%$ silt, $22 \%$ clay) with EC $1.4 \mathrm{dS} / \mathrm{m}^{-1}$. Water irrigation was also analyzed according to the methods described by American Public Health Association (APHA) [30]; the soil sites were prepared as recommended and divided into subplots. Each subplot consisted of eight rows, $2 \mathrm{~m}$ long and $20 \mathrm{~cm}$ apart. The total plot area was $3.2 \mathrm{~m}^{2}$. The rate of $70 \mathrm{~kg}$ $\left(\mathrm{P}_{2} \mathrm{O}_{5}\right)$ /ha in the form of super phosphate $\left(16 \% \mathrm{P}_{2} \mathrm{O}_{5}\right)$ and potassium fertilizer, in the form of potassium sulphate $\left(42 \% \mathrm{~K}_{2} \mathrm{O}\right)$ by the rate of $100 \mathrm{~kg} / \mathrm{ha} \mathrm{K}_{2} \mathrm{O}$, were applied broadcasting during soil preparation, whereas the recommended dose of $\mathrm{N}$ (100 kg N/ha) was also applied in three split equal doses in the form of ammonium nitrate $(33.3 \% \mathrm{~N})$ at sowing, during tillering and at anthesis. Seeds of each genotype were sown at a rate of $140 \mathrm{~kg} / \mathrm{ha}$ by the hand drilled method on December 10 and 14 in the first and second season, respectively. With the exception of the experimental treatments, all agriculture practices for sowing wheat were carried out according to the conventional production practices followed in the Riyadh area. The irrigation system was a flooding irrigation system through line pipes provided by meter gages for measuring the water applied.

At harvest time, the inner four rows of each subplot unit were harvested to estimate yield and yield component characteristics. Water use efficiency (WUE) was calculated based on biological yield, according to the formula suggested by Bos [23] as follows:

$\mathrm{WUE}_{\mathrm{b}}=$ above ground biomass as $(\mathrm{kg})$ divided by seasonal water used in ET. ET is the amount of water used by the plants over the growing season in $\mathrm{m}^{3}$. The harvest index (HI) and crop index (CI) were also calculated using the formula suggested by Donald and Humblin [24].

\subsection{Statistical analysis}

Data for each season were statistically analyzed according to the methods described by Gomez and Gomez [25]. The means were compared using least the significant difference test (LSD). However, the data obtained showed no 
significant differences between the two seasons of the study, therefore a combined analysis over the two growing seasons was done.

\subsection{Economic evaluation}

The economic evaluation of the data obtained herein was done based on the cost of inputs and outputs that prevailed during the period of experimentation as follows.

The gross return was worked out by multiplying the economic produce and by-produce (straw, haulm etc.) by respective sale prices and expressed in SR $\mathrm{ha}^{-1}$. The net return for the data obtained was worked out by subtracting the total cost of cultivation from the total gross returns and expressed in SR $\mathrm{ha}^{-1}$. The return $\mathrm{SR}^{-1}$ invested was calculated by dividing the gross returns by the total cost of cultivation.

\section{Results}

The data presented in Tables 3 and 4 manifests the effect of water irrigation treatments at different cumulative pan evaporation, CPE on grain yield and yield component characters of the four wheat genotypes. It is clearly obvious that low water supply treatments reduce all yield component characters under investigation. The data given elucidates that tillers number $/ \mathrm{m}^{2}$ was significantly reduced as irrigation supplies decreased. The highest number of tillers $/ \mathrm{m}^{2}(583.7)$ was recorded at $50 \mathrm{CPE}$, whereas the lowest number (499.4) was obtained when water irrigation was supplied at $200 \mathrm{CPE}$. The same picture was also observed in plant height: gradual decrease was in line with decreasing cumulative pan

Table 3: $\quad$ Effect of water irrigation levels on some yield and yield component characters of wheat genotypes (mean of two growing seasons of $2003 / 2004$ and 2004/2005).

\begin{tabular}{|c|c|c|c|c|c|c|c|}
\hline $\begin{array}{c}\text { Irrigation } \\
\text { treat. at } \\
\text { CPE } \\
(\mathrm{mm})\end{array}$ & $\begin{array}{c}\text { Mean of } \\
\text { water } \\
\text { applied } \\
\mathrm{m}^{3} / \mathrm{ha}\end{array}$ & $\begin{array}{c}\text { Plant } \\
\text { height } \\
\mathrm{cm}\end{array}$ & $\begin{array}{c}\text { Tillers } \\
\text { number/m }\end{array}$ & $\begin{array}{c}\text { Grain } \\
\text { yield } \\
\text { ton/ha }\end{array}$ & Decreasing \% & \multicolumn{2}{|c|}{$\begin{array}{c}\text { Water } \\
\text { conserving }\end{array}$} \\
\cline { 5 - 9 } $\mathrm{m}^{3} / \mathrm{ha}$ & $\%$ \\
\hline 50 & 8000 & 93.1 & 583.7 & 6.87 & 2.41 & 2000 & 20 \\
\hline 100 & 6000 & 77.1 & 517.5 & 5.97 & 15.20 & 4000 & 40 \\
\hline 150 & 4000 & 79.0 & 510.6 & 4.99 & 26.12 & 6000 & 60 \\
\hline 200 & 2000 & 73.6 & 499.4 & 4.48 & 36.36 & 8000 & 80 \\
\hline \multicolumn{2}{|c|}{ LSD $_{(0.05)}$} & 5.2 & 46.8 & 0.60 & ------ & ---- & --- \\
\hline
\end{tabular}


56 Sustainable Irrigation Management, Technologies and Policies III

Table 4: Effect of water irrigation levels on some yield component parameters of wheat genotypes (mean of two growing seasons of 2003 /2004 and 2004/2005).

\begin{tabular}{|c|c|c|c|c|c|c|}
\hline $\begin{array}{c}\text { Irrigation } \\
\text { treat. at CPE } \\
(\mathrm{mm})\end{array}$ & $\begin{array}{c}\text { Mean of } \\
\text { water } \\
\text { applied } \\
\mathrm{m}^{3} / \mathrm{ha}\end{array}$ & $\begin{array}{c}\text { Straw yield } \\
\text { ton/ha }\end{array}$ & $\begin{array}{c}\text { Biological } \\
\text { Yield ton/ha }\end{array}$ & $\begin{array}{c}\mathrm{WUE} \\
\mathrm{Kg} / \mathrm{m}^{3} / \mathrm{ha}\end{array}$ & $\begin{array}{c}\text { Filling } \\
\text { period } \\
\text { (day) }\end{array}$ & $\begin{array}{l}\mathrm{CI} \\
\%\end{array}$ \\
\hline Control & 10000 & 13.6 & 19.8 & 0.70 & 56.2 & 55.2 \\
\hline 50 & 8000 & 12.8 & 18.3 & 0.86 & 57.3 & 60.1 \\
\hline 100 & 6000 & 10.5 & 15.8 & 1.00 & 55.3 & 60.7 \\
\hline 150 & 4000 & 10.8 & 14.0 & 1.25 & 53.6 & 55.4 \\
\hline 200 & 2000 & 9.5 & 12.8 & 2.24 & 52.3 & 53.8 \\
\hline \multicolumn{2}{|c|}{ LSD $_{(0.05)}$} & 1.5 & 1.40 & 0.22 & 3.8 & --- \\
\hline
\end{tabular}

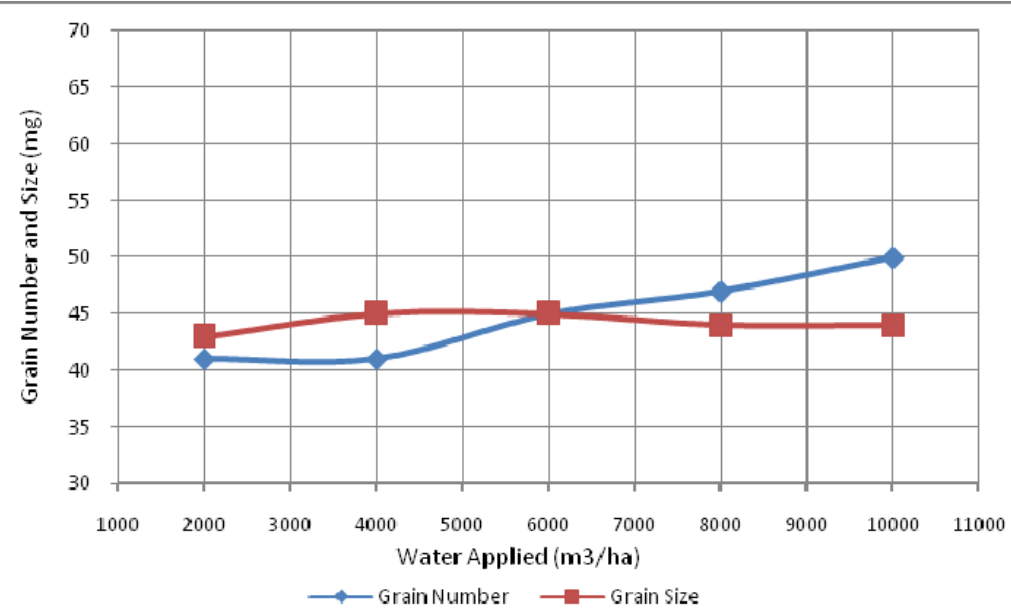

Figure 1: Grain number and size $(\mathrm{mg})$ as effected by irrigation levels during the two growing seasons (2003/2004 and 2004/2005).

evaporation. The decrement was 77.1, 79.0 and 73.6 accompanied with irrigation treatments of 100, 150 and $200 \mathrm{CPE}$, respectively, as compared to the highest value. Noticeably, plants given the highest irrigation level (control) recorded lower values of tillers number $/ \mathrm{m}^{2}$, plant height, filling period and WUE as compared to irrigation water supplies at 50 cumulative pan evaporation. In addition, as expected grain yield was significantly decreased with decreasing 
Table 5: Effect of genotypic variations on some growth characters of wheat genotypes (mean of the two growing seasons of 2003/2004 and 2004/2005).

\begin{tabular}{|c|c|c|c|c|c|}
\hline Genotype & $\begin{array}{c}\text { Plant } \\
\text { height cm }\end{array}$ & $\begin{array}{c}\text { Tillers } \\
\text { number } \\
/ \mathrm{m}^{2}\end{array}$ & $\begin{array}{c}\text { Grain } \\
\text { number/ } \\
\text { Spike }\end{array}$ & Grain Size mg & $\begin{array}{c}\text { Grain filling } \\
\text { rate } \\
\left(\mathrm{g} / \mathrm{m}^{2} / \text { day }\right)\end{array}$ \\
\hline Yecora Rojo & 70.28 & 590 & 34.4 & 47.7 & 7.6 \\
\hline West Bread & 84.86 & 482 & 49.4 & 37.8 & 9.6 \\
\hline KSU 102 & 77.87 & 580 & 58.2 & 39.6 & 7.7 \\
\hline KSU 105 & 82.09 & 596 & 44.8 & 43.3 & 11.2 \\
\hline LSD $(0.05)$ & 4.8 & 6.5 & 3.1 & 2.1 & 0.74 \\
\hline
\end{tabular}

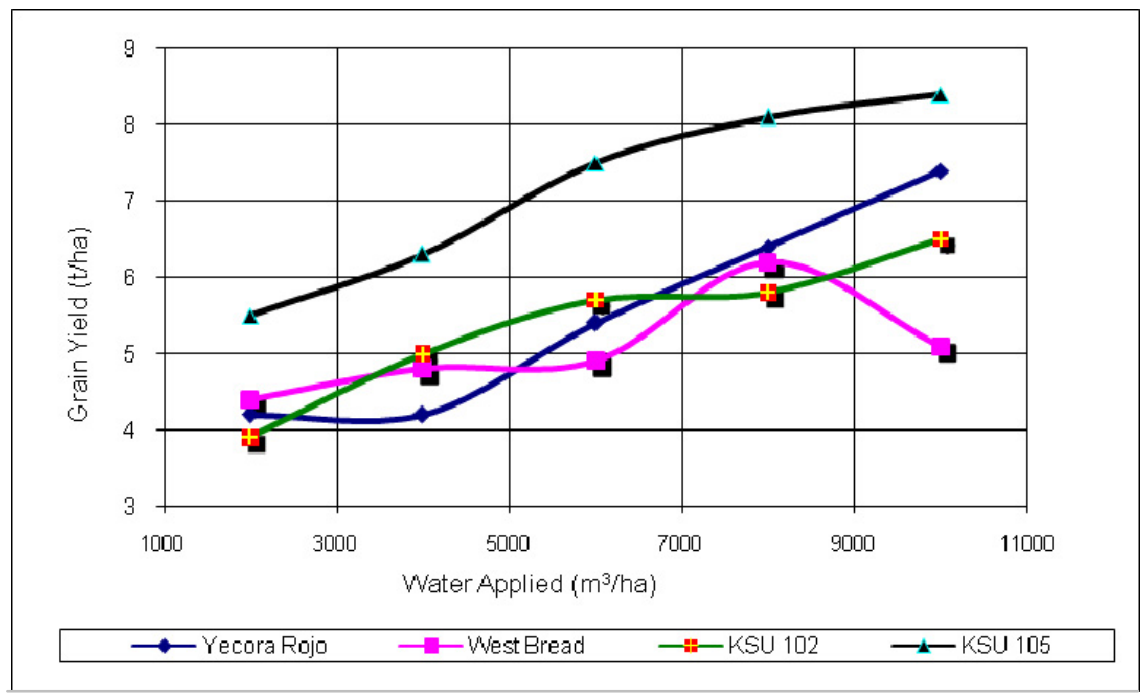

Figure 2: Yield productivity of four cultivars of wheat $(\mathrm{t} / \mathrm{ha})$ as effected by irrigation levels during the two growing seasons (2003/2004 and 2004/2005).

water irrigation levels irrespective of genotypes. With respect to grain yield (ton/ha), the results obtained indicated that the differences between the traditional method of water supply (7.04 ton/ha) and irrigation water applied at $50 \mathrm{~mm}$ of CPE (6.87 ton/ha) was not significant. Moreover, Fig 1 illustrates that grain number and grain size were affected by levels of irrigation supplies. Both characters were gradually decreased by increasing water deficit as a result of decreasing water irrigation level. Fig 2 also reveals that the tested four genotypes were different in their response to the water supply schedules. Promising 
genotype KSU105 surpassed the other genotypes and recorded the highest grain yield.

As regards genotypic variation, the data obtained demonstrated that advanced line KSU 105 outranked the other three genotypes and recorded the highest values of the most of studied characters under investigation viz., tillers number $/ \mathrm{m}^{2}$ (596), grain yield (7.14) ton/ha, biological yield (18.4) ton/ha and water use efficiency, $\mathrm{Kg} / \mathrm{m}^{3} / \mathrm{ha}$ as compared to the lowest values of the same attributed parameters were recorded by the West Bread variety viz., tillers number $/ \mathrm{m}^{2}$ (482), grain yield ton/ha (5.06), biological yield ton/ha (13.9) and water use efficiency, $\mathrm{Kg} / \mathrm{m}^{3} / \mathrm{ha}$ (Tables 5 and 6 ).

Concerning the effect of interactions between the two factors under investigation, i.e., genotypes $\mathrm{x}$ water irrigation schedule supply, the data obtained clearly indicated that by sowing line KSU105 in the presence of the highest level of irrigation water $\left(10000 \mathrm{~m}^{3} / \mathrm{ha}\right)$, the highest grain yield was obtained (8.41 ton/ha). Moreover, the data reveal that no significant differences between these treatments and a water irrigation at the level of $8000 \mathrm{~m}^{3} / \mathrm{ha}$, which recorded grain yield 8.08 ton/ha (Table 7).

With regard to economic evaluation, the results obtained in the present investigation, presented in (Table 8), reveal that the highest net return (2082.69 SR) and highest invested return per SR (1.37) were obtained by the irrigation of wheat plants under an arid environment at 50 followed by $100 \mathrm{CPE}$ as compared to the other irrigation treatments.

\section{Discussion}

Drought is a global problem that is reducing plant growth and productivity worldwide; some of the most severe water deficits in root zones occur in arid and

Table 6: Means of yield and yield component characteristics of wheat genotypes as affected by genotypic variations (mean of the two growing seasons of 2003/2004 and 2004/2005).

\begin{tabular}{|l|c|c|c|c|c|c|}
\hline \multicolumn{1}{|c|}{ Genotype } & $\begin{array}{c}\text { Biological } \\
\text { Yield } \\
\text { ton/ha }\end{array}$ & $\begin{array}{c}\mathrm{WUE}_{(\mathrm{g})} \\
\left(\mathrm{Kg} / \mathrm{m}^{3} / \mathrm{ha}\right)\end{array}$ & $\begin{array}{c}\text { Straw } \\
\text { yield } \\
\text { ton/ha }\end{array}$ & $\begin{array}{c}\text { Grain } \\
\text { yield } \\
\text { ton/ha }\end{array}$ & $\begin{array}{c}\mathrm{HI} \\
\%\end{array}$ & $\begin{array}{c}\mathrm{CI} \\
\%\end{array}$ \\
\hline Yecora Rojo & 16.7 & 1.11 & 8.40 & 5.50 & 39.6 & 65.5 \\
\hline West Bread & 13.9 & 1.09 & 11.64 & 5.06 & 30.3 & 43.5 \\
\hline KSU 102 & 16.2 & 1.11 & 10.81 & 5.39 & 33.3 & 49.9 \\
\hline KSU 105 & 18.4 & 1.48 & 11.26 & 7.14 & 38.8 & 63.4 \\
\hline LSD $_{(0.05)}$ & 0.8 & 0.12 & 0.42 & 0.40 & ------ & ----- \\
\hline
\end{tabular}


Table 7: $\quad$ Means of interaction effect between irrigation levels and genotypic variation on grain yield of wheat genotypes (means of the two growing seasons of 2003/2004 and 2004/2005).

\begin{tabular}{|c|c|c|c|c|c|}
\hline $\begin{array}{c}\text { Irrigation } \\
\text { treat. at CPE } \\
(\mathrm{mm})\end{array}$ & $\begin{array}{c}\text { Mean water } \\
\text { applied } \\
\mathrm{m}^{3} / \mathrm{ha}\end{array}$ & $\begin{array}{c}\text { Yecora Rojo } \\
\text { ton/ha }\end{array}$ & $\begin{array}{c}\text { West Bread } \\
\text { ton/ha }\end{array}$ & $\begin{array}{c}\text { KSU102 } \\
\text { ton/ha }\end{array}$ & $\begin{array}{c}\text { KSU105 } \\
\text { ton/ha }\end{array}$ \\
\hline Control & 10000 & 7.34 & 5.13 & 6.53 & 8.41 \\
\hline 50 & 8000 & 6.38 & 6.15 & 5.77 & 8.08 \\
\hline 100 & 6000 & 5.43 & 4.92 & 5.72 & 7.44 \\
\hline 150 & 4000 & 4.17 & 4.75 & 5.02 & 6.31 \\
\hline 200 & 2000 & 4.19 & 4.36 & 3.92 & 5.47 \\
\hline $\mathrm{LSD}_{(0.05)}$ & & 0.89 & 0.89 & 0.89 & 0.89 \\
\hline
\end{tabular}

Table 8: Economic evaluation of the effect of irrigation schedules on some wheat genotypes grown under the arid environment of Saudi Arabia (mean of the two growing seasons of 2003/2004 and 2004/2005).

\begin{tabular}{|c|c|c|c|c|c|}
\hline $\begin{array}{c}\text { Irrigation } \\
\text { treat. at CPE } \\
(\mathrm{mm})\end{array}$ & $\begin{array}{c}\text { Mean of water } \\
\text { applied } \\
\mathrm{M}^{3} / \mathrm{ha}\end{array}$ & $\begin{array}{c}\text { Gross } \\
\text { return } \\
(\mathrm{SR})\end{array}$ & $\begin{array}{c}\text { Total costs } \\
\text { (SR) }\end{array}$ & $\begin{array}{c}\text { Net return } \\
\text { (SR) }\end{array}$ & $\begin{array}{c}\text { Return } \\
\text { per SR } \\
\text { invested }\end{array}$ \\
\hline Control & 10000 & 7898.18 & 7019.2 & 879.0 & 1.13 \\
\hline 50 & 8000 & 7701.89 & 5619.2 & 2082.69 & 1.37 \\
\hline 100 & 6000 & 6692.91 & 5419.2 & 1273.71 & 1.24 \\
\hline 150 & 4000 & 5594.24 & 5219.2 & 375.04 & 1.07 \\
\hline 200 & 2000 & 5022.48 & 5019.2 & 3.28 & 1.00 \\
\hline
\end{tabular}

SR: Saudi Riyal (1 \$ USA = 3.75 SR).

semiarid regions of the world, where limited rainfall, high evapo-transpiration and high temperature play a very important role in leaf water content and plant water required. To solve the problem of drought two strategies could be used: provide plants with water by irrigation and/or selecting drought-tolerant genotypes. However, the cost and availability of irrigation water under arid and semiarid conditions make the irrigation approach unfeasible on a large scale. In respect of water supplies, previous results indicated that significant reduction in most of the yield and yield component characteristics was noticed due to 
decreasing water supply levels (Tables 3 and 4). Such effect of water supply may be due to the availability of water in the root zone promoted growth and proliferation of the root and thereby increased the absorption of water and soluble nutrients, resulting in a higher number of leaves per plant and large leaves, leading to increased LA. All of these parameters put together increase the rate of photosynthesis; better translocation of photosynthesis from leaves and stems to the sink finally favourably influenced the yield and yield component characteristics. Similar results were also reported in $[1-6,11]$. In addition, the same trend was discussed by many authors [7-10, 12-14, 27, 28] who reported that low soil moisture content caused an irreversible loss in yield potential.

In the present study, yield and yield components were showed to be significantly affected by varietal differences. Among the cultivars used, line KSU-105 produced the highest grain yield (7.14 ton/ha) followed by Yecora Rojo (5.50 ton/ha), KSU-102(5.39 ton/ha) and West Bread (5.06 ton/ha). The superiority of line KSU- 105 may be because the selection of line KSU-105 was done at the same location as the present experiment. Thus, it has higher adaptability genetic constituencies toward drought conditions than the other tested genotypes. These results are in general agreement with those obtained in $[15-20,26,29]$. In the respect of water supply and varietal difference interactions, the data obtained in the present study (Table 6) indicate the importance of proper genotypes, which corroborated the findings of Ashour and Selim [28], who concluded that the effect of genotypic variations is one of the most important strategies for improving crop production.

\section{Conclusion}

According to the results obtained herein, it can be concluded that sustainable irrigation management under our arid regions can be achieved through selecting the most efficient irrigation schedule methods, such as CPE, where much of the water irrigation supply can be conserved in addition to adapting highly drought tolerant genotypes to achieve greater crop productivity and to reach sustainability under the stress conditions of arid and semiarid regions.

\section{References}

[1] Salter, P.J. and Goode, J.E., Crop response to water at different stages of growth. Res. Rev., common Bur-of Hortic. Plant Crops, No.2, 16, 1976

[2] Misra, R.D., Charma, K.C., Wright, B.C. and Sing, V.P., Critical stages in irrigation and irrigation requirements of wheat variety. Indian J. Agric. Sci. 39(9), 898, 1969.

[3] Chauhan, D.S., Hukkeri, S.B. and Dastance, N.G., Intensive versus extensive irrigation. Indian J. of Agron. 15(1), 46, 1970.

[4] Abd El-Ghany, H.M., Wheat production under water-limited sandy soil conditions using bio-organic fertilizer system. Egypt. J. Agron. Vol.29, No.1, 17-27, 2007. 
[5] Hussain, G. and Al-Jaloud, A., Effect of irrigation and nitrogen on water use efficiency of wheat in Saudi Arabia. Agric. Water Manage., 27: 143$153,1995$.

[6] Ghandorah, M.O., El-Shawaf, I.I., Moustafa, Kh.A. and Gadallah, A.M., Evaluation of some early generations of bread wheat genotypes grown under heat and water stress at the central region of Saudi Arabia. Arab. Gulf J. Science. Res., 15(2): 505-523, 1997.

[7] Kramer, P.J. and Boyer, J.S., Water relation of Plant and Soils. Academic Press, San Diego, USA. pp4 95, 1995.

[8] Alderfasi, A.A., Ghandorah M.O. and. Mustafa, Kh.A., Evaluation of some wheat genotypes under drought stress in arid region of Saudi Arab Alex. J. Agric. Res. 44(3): 209-213, 1999.

[9] Reginato, R.J., Field quantification of crop water stress. ASAE, 26: 772$775,1993$.

[10] Reginato, R.J. and Carrot D.J., Irrigation scheduling with the crop water stress index. (C.F.springerLink- www.springlink.com), 1997.

[11] Imtiyaz, M., Mgadla, N.P. and Chepeze, B., Irrigation scheduling for vegetable and field crops. Irrigation Research paper 1, Department of Agriculture Research, Botswana, 36-42, 1994.

[12] Imtiyaz, M., Mgadla N.P., Chepeze B. and Manase, S.K., Response of six vegetable crop to irrigation schedules. Agriculture Water Management 45: 331-342, 2000.

[13] Pawar, J.K., Dhomane, A.S. and More, V.D., Studies on scheduling of irrigation and nitrogen levels on yield of summer sunflower. J. Indian Water. Res. Soc. 11(1): 57-59, 1991.

[14] Singh, S., Ram, M., Ram, D., Sharns, S. and Singh, D.V., Water requirement and productivity of palmarosa on sandy loam soil under subtropical climate. Agric. Water. Manag. 35: 1-10, 1997.

[15] El-Haddad, E.H., Amer, M.A. and Moistafa, M.A., Effect of salinity on the growth and yield of three wheat cultivars grown in calcareous soil. Menofiya J. Agric. Res. 18(3), 1669, 1993.

[16] Yousef, K.M.R. and Hanna, N.S., Evaluation of some bread wheat varieties to yield and water relations at Fayoum Governorate. Fayoum J. Agric. Res. \& Dev. 12(2), 216, 1998.

[17] El-Beially, I.E.M.A, Effect of irrigation with saline water on growth, yield and its components of some wheat cultivars in sandy soil. Al-Azhar J. Agric. Res. 34, 59, 2001.

[18] Hassan, A.I., Moselhy, N.M.M. and Abd El-Maboud, MSh, Evaluation of some wheat cultivars under two levels of irrigation water salinity in calcareous soils, South Sinai. Zagazig J. Agric. Res. 29(1), 1, 2002.

[19] Abd Allah, A.E., Moustafa, M.A. and Salem, M.A., Interactive effect of saline irrigation water and zinc application on growth and yield of seven wheat cultivars grown in calcareous soil. J. Adv. Agric. Res. 8(3), 551, 2003. 
[20] Reiad, M. Sh., Yasein, M., Tolba, A.M. and Abd-El-Samie, F.S., Effect of wheat genotypes, drought and soil salinity on growth, yield and its components. Egypt J. Agron Vol.29, No.1, pp.69-83, 2007.

[21] Cottenie, A. M., Verlo, L., Kjekens and Camerlynch, R., Chemical Analysis of Plant and Soil. Laboratory of Analytical Agro chemistry. State Univ. Gent, Belgium. No.42, pp.280-284, 1982.

[22] But, R., Soil Survey laboratory Manual Report No.42 USDA, National Resources Conservation Service .Washington, 2004.

[23] Bos, M.G., Summary of ICID definition of irrigation efficiency, ICID Bull, 34, 28-31, 1985.

[24] Donald, C.N. and Humblin J., The biological yield and harvest index of cereals as agronomic and plant breeding criteria. Adv. Agron., 28: 361-405, 1976.

[25] Gomez, K. A. and Gomez, A., Statistical Procedures for Agricultural Research $2^{\text {nd }}$ ed. John Wiley \& Sons, New York, 1984.

[26] Aderfasi, A.A., Response of four genotypes of wheat to irrigation schedules. Saudi. J. Biol. Sci., 7(2): 171-178, 2000.

[27] Aderfasi, A.A., Yield potential of two barley genotypes grown under water stress of arid ecosystem of Saudi Arabia, Am-Euras. J. Agric. \& Environment. Sci.: 5(3): 348-353, 2009.

[28] Ashour, N.I. and Selim, M.M., Growth and Yield responses of some wheat cultivars to saline conditions in South Sinai Governorate. Egypt J. Agron. 19, No.1-2, pp. 139-148, 1994.

[29] Ghahrome, B. and Sepaskhah, A.R., Use of a water deficit sensitivity index for partial irrigation scheduling of wheat and barley. (C.F.springerLink www.springlink.com, 1998.

[30] American Public Health Association, Standard Methods for Examination of Water and Wastewater, 18th (ed) APHA, AWWA, WPCF, NY, Washington, 1992. 